\title{
Correlation between Bacterial Vaginosis and Adverse Pregnancy Outcome
}

\author{
Michael F.E. Diejomaoh a Vincent O. Rotimi ${ }^{\mathrm{b}}$ Alexander E. Omu ${ }^{\mathrm{a}}$ \\ Sanjit Fernandes ${ }^{a}$ Noura A. Al-Sweih ${ }^{c}$ Majda Al-Yatama ${ }^{a}$ \\ Shameem Malik ${ }^{b}$ \\ Departments of a Obstetrics and Gynaecology and ${ }^{\mathrm{b}}$ Microbiology, Faculty of Medicine, \\ Kuwait University and cMaternity Hospital, Kuwait
}

\section{Key Words}

Bacterial vaginosis · Pregnancy · Adverse outcome of pregnancy

\begin{abstract}
Objective: The main purpose of this study was to investigate the role of bacterial vaginosis (BV) in prematurity, premature rupture of membranes (PROM) and other disorders of pregnancy. Methods: High vaginal and cervical swabs were taken from pregnant women in the second and third trimesters of pregnancy and from 30 non-pregnant women. Informed consent was obtained from all potential subjects. The specimens were smeared, gram-stained and cultured on a variety of selective and non-selective media which were then incubated at the appropriate atmospheres. Vaginal $\mathrm{pH}$, character of the discharge, and outcome of the amine test were noted. Ultrasound was performed to
\end{abstract}

\begin{tabular}{ll}
\hline KARGER & (1) 1999 S. Karger AG, Basel \\
Fax +41 61 306 1234 34 & \\
$\begin{array}{l}\text { E-Mail karger@karger.ch } \\
\text { www.karger.com }\end{array}$ & $\begin{array}{l}\text { Accessible online at: } \\
\text { http://BioMedNet.com/karger }\end{array}$
\end{tabular}

confirm gestational age and all pregnant women followed up until postpartum. $\boldsymbol{R e}$ sults: A total of 123 pregnant women were evaluated at the end of the study. BV was diagnosed clinically and bacteriologically in 34 women, giving a prevalence rate of $28 \%$. BV was diagnosed in none of the 30 nonpregnant control patients. Fifty-four percent and $46 \%$ of the study population were $\mathrm{Ku}$ waitis and non-Kuwaitis, respectively. The mean parity recorded was $2.24 \pm 2.06$. There was a positive correlation between $\mathrm{BV}$ and preterm labour (9/34, 27\%; $\mathrm{Cl}, \mathrm{p}<0.05)$, PROM (7/34, 21\%: $\mathrm{Cl}$; $\mathrm{p}<0.05)$ and preterm delivery (7/34, 21\%; $\mathrm{Cl}, \mathrm{p}<0.05)$. Three (9\%) of the women with BV had babies with intrauterine growth retardation compared with 1 $(1 \%)$ in the 89 non-BV group ( $p<0.05)$. Conclusion: The prevalence rate of $\mathrm{BV}$ among pregnant women in Kuwait is high and is significantly associated with prematurity and other disorders of pregnancy.

Prof. V.O. Rotimi, MD, PhD, FRCPath

Department of Microbiology, Faculty of Medicine Kuwait University, PO Box 24923

Safat 13110, Kuwait, Tel. +965 5312300, Ext. 6509

Fax+965 5318454, E-Mail Vincent@hsc.kuniv.edu.kw 


\section{Introduction}

Prematurity is a major problem in obstetrics world-wide and in spite of all efforts to reduce the incidence by focusing on the elimination of some of the aetiological factors, preterm birth remains an important contributor to perinatal morbidity and mortality [1-5]. Research efforts have continued to identify more causes of prematurity with a view to eliminating such problems. Many studies have confirmed the role of bacterial vaginosis (BV) in prematurity. Some of the studies have shown that treatment of $\mathrm{BV}$ leads to the reduction of the incidence of prematurity [69]. Recent interests have also focused on a probable role for $\mathrm{BV}$ in recurrent abortions [6, $10,11]$. In spite of the volume of research in the area of BV in pregnancy $[6-9,12,13]$, there still remain many unanswered questions such as the natural course of bacterial vaginosis in pregnancy $[13,14]$.

As far as we are aware, the prevalence of $\mathrm{BV}$ in pregnant women and its associated adverse effect on pregnancy outcome have not been studied in Kuwait. From our personal unpublished observations, prematurity and intra-uterine growth retardation (IUGR) are important obstetric problems in Kuwait. Therefore, the main objective of this study was to establish the prevalence of BV in pregnant women in Kuwait, as well as to investigate the role of $\mathrm{BV}$ in prematurity and other disorders of pregnancy.

\section{Material and Methods}

A total of 165 pregnant women were initially enrolled in the study, which was conducted at the Maternity Hospital, Kuwait, during the period of 1 year, from January to December 1998. The women were fully counselled and their informed consent obtained. All patients who presented at their first antenatal visit were interviewed and their social, obstetric and medi- cal history were carefully documented in a designed pro forma. High vaginal and endocervical swabs were taken from the subjects under direct vision, using the Cusco speculum. Ultrasound examination was carried out to confirm the gestational age. At each visit, the progress of pregnancy and associated events were recorded. All the cases were followed up through labour, delivery and during puerperium. Cases of premature labour, premature rupture of membrane, and premature delivery were noted, as were cases of idiopathic IUGR. Vaginal specimens were also obtained from 30 non-pregnant women, who attended the gynaecology clinic for reasons other than genital infections, and were studied for comparison.

\section{Exclusion Criteria}

At the end of the study, 42 patients were excluded from the evaluation. These included patients who had conditions that might predispose to prematurity and preterm labour, such as diabetes mellitus, multiple pregnancy, hypertension, kidney disease, cardiac disease, cervical incompetence/cerclage and haemoglobinopathies. Other cases that were excluded were those who had antibiotic treatment for about 2-4 weeks before the commencement of the study.

\section{Specimens}

Vaginal specimens (high vaginal swab and cervical swab) were obtained by the obstetricians in our team, under direct vision using unlubricated Cusco's speculum. Duplicate high vaginal swabs and cervical swabs were collected in Amies' transport medium (Unipath, Basingstoke, UK) and Mycoplasma transport medium and sent to the Anaerobe Research Laboratory, Department of Microbiology, Faculty of Medicine, where they were processed within $2 \mathrm{~h}$ of collection. The characteristic discharge such as quantity, colour and smell were noted and $\mathrm{pH}$ determined directly using the $\mathrm{pH}$ indicator paper at the time of specimen collection. One to two drops $(10 \%)$ of $\mathrm{KOH}$ was added to a wet smear of the discharge by the examining obstetrician and sniffed; an immediate fishy odour was regarded as a positive amine test and recorded.

The clinical diagnosis of bacterial vaginosis was made when three of the following four criteria were met: a vaginal $\mathrm{pH}$ of $\geq 4.5$, presence of thin homogeneous discharge, presence of 'clue' cells and a positive amine test. The subject was considered normal if at least three of these criteria were not met and neither yeasts nor trichomonads were detected and the vaginal smear was mainly lactobacilli morphotypes. 
Table 1. Characteristics of pregnant and non-pregnant healthy women

\begin{tabular}{|c|c|c|c|c|}
\hline \multirow[t]{2}{*}{ Characteristic } & \multicolumn{2}{|c|}{$\begin{array}{l}\text { Pregnant } \\
(\mathrm{n}=123)\end{array}$} & \multicolumn{2}{|c|}{$\begin{array}{l}\text { Non-pregnant } \\
(\mathrm{n}=30)\end{array}$} \\
\hline & $\mathrm{n}$ & $\%$ & $\mathrm{n}$ & $\%$ \\
\hline \multicolumn{5}{|l|}{ Vaginal $\mathrm{pH}$} \\
\hline$<4.5$ & 62 & 50 & 29 & 96.7 \\
\hline$\geq 5.0$ & 61 & 49.6 & 1 & 3.3 \\
\hline \multicolumn{5}{|l|}{ Quality of discharge } \\
\hline None & 49 & 39.8 & 30 & 100 \\
\hline Small & 40 & 32.5 & 0 & 0 \\
\hline Moderate & 29 & 23.6 & 0 & 0 \\
\hline Profuse & 5 & 4.1 & 0 & 0 \\
\hline Malodorous & 25 & 20.3 & 0 & 0 \\
\hline \multicolumn{5}{|l|}{ Colour/type of discharge } \\
\hline White & 70 & 56.9 & 20 & 66.7 \\
\hline Mucoid/white & 25 & 20.3 & 7 & 23.3 \\
\hline Creamy & 18 & 14.6 & 3 & 10 \\
\hline Greyish-frothy & 6 & 4.9 & 0 & 0 \\
\hline Yellowish-frothy & 4 & 3.3 & 0 & 0 \\
\hline Positive amine test & 7 & 5.7 & 0 & 0 \\
\hline Presence of 'clue cells' & 33 & 26.8 & 0 & 0 \\
\hline Pus cells present & 4 & 3.3 & 3 & 10 \\
\hline
\end{tabular}

\section{Microscopic Examination}

The microscopic examinations and assessment of the smears for the presence of bacterial vaginosis were carried out by the modified criteria described by Rosenstein et al. [15] and a modified semiquantitative method described by Rotimi et al. [16]. Briefly, in wet films, an estimate of the Lactobacillus and Gardnerella morphotypes was made into the following schemes: $1^{+}=1 /$ field; $2^{+}=1-5 /$ field; $3^{+}=6-30 /$ field; $4^{+}=>30 /$ field. Thus, a $3^{+}-4^{+}$Gardnerella morphotype with $1^{+}$or no Lactobacillus morphotype was regarded as grade III, i.e. abnormal. A $2^{+}-3^{+}$Gardnerella morphotype plus $2^{+}$Lactobacillus morphotype was regarded as intermediate, grade II, and a $>3^{+}$Lactobacillus morphotype plus $1^{+}$or no Gardnerella morphotype as normal, grade I vaginal flora.

\section{Bacterial Culture and Identification}

The following media were used for primary culture: selective brain-heart infusion agar (SBHIA) for Gardnerella vaginalis, comprising of brain-heart infusion agar (Unipath) with expired human blood 5\%, neomycin $75 \mathrm{mg} / \mathrm{l}$ and colistin $10 \mathrm{mg} / \mathrm{l}$ [17], selective chocolate agar (Blood Agar Base No. 2; Unipath) with expired human blood $10 \%$, vancomycin $3 \mathrm{mg} / 1$ and colistin $7.5 \mathrm{mg} / \mathrm{l}$, and Thayer-Martin agar (Unipath) for Neisseria gonorrhoeae; Sabouraud dextrose agar (Unipath) for cultivation of Candida spp.; PPLO agar (Difco Laboratories, Mich., Detroit, USA) and Mycoplasma IST broth (bioMérieux SA, Lyon, France) for Mycoplasma hominis and Ureaplasma urealyticum and Rogosa agar (Unipath) for cultivating Lactobacillus spp.; $\mathrm{H}_{2} \mathrm{O}_{2}$-producing lactobacilli were detected by quantitative assays on a tetramethylbenzidine agar incubated anaerobically for 5 days [18]. Brucella agar (Difco Laboratoires), supplemented with 5\% lysed horse blood, was used for the cultivation of Mobiluncus spp. Colonies appearing translucent on Brucella agar, curved gram-negative bacilli on smear, actively motile in wet preparation, and indole-, oxidase- and catalase-negative were identified as Mobiluncus spp.

$N$. gonorrhoeae and Candida spp. were identified by standard methods [19]. Isolates that produce tiny $\beta$-haemolytic colonies on SBHIA were gram-stained and catalase-tested and those presumptively identified as $G$. vaginalis were confirmed by a battery of biochemical tests [16]. Typical large gram-positive bacilli from non-haemolytic colonies were presumptively identified as lactobacilli. M. hominis and $U$. urealyticum were identified by Mycoplasma IST kit according 
Table 2. Characteristics of pregnant women with or without BV

\begin{tabular}{lll}
\hline Characteristics & \multicolumn{2}{l}{ Clinical diagnosis } \\
\cline { 2 - 3 } & $\begin{array}{l}\text { with BV } \\
(\mathrm{n}=34)\end{array}$ & $\begin{array}{l}\text { without BV } \\
(\mathrm{n}=89)\end{array}$ \\
\hline Demographics & & \\
$\quad$ Kuwaitis, $\mathrm{n}(\%)$ & $16(47)$ & $50(56)$ \\
$\quad$ Non-Kuwaitis, $\mathrm{n}(\%)$ & $18(53)$ & $39(44)$ \\
Age, years & $29.68 \pm 5.3$ & $28.75 \pm 5.1$ \\
Reproductive history & & \\
$\quad$ Nulliparous & 10 & 23 \\
$\quad$ Previous preterm delivery & 6 & 5 \\
$\quad$ Previous spontaneous abortion & 7 & 12 \\
Infertility & 0 & 0 \\
\hline
\end{tabular}

The mean parity for all women was $2.24 \pm 2.06$. to the manufacturer's standard procedures for the diagnosis of urogenital Mycoplasma (bioMérieux).

\section{Statistical Analysis}

The data were analysed by $\chi^{2}$ statistical test for univariate comparisons of proportions, with or without Yates' corrections, between women with or without bacterial vaginosis, using SPSS statistical package for Windows.

\section{Results}

\section{General Characteristics}

Of the 165 women enrolled, 123 could be evaluated. The general characteristics and clinical features of the 123 pregnant and 30 non-pregnant women are summarized in table 1 . Small to moderate vaginal discharge was present in $74(60 \%)$ of the 123 pregnant women and was malodorous in $25(20 \%)$. The discharge was white in $70(57 \%)$, mucoid and white in $25(20 \%)$ and creamy in $18(15 \%)$. Amine test was positive in only $7(6 \%)$ cases and the presence of 'clue cells' was recorded in $33(27 \%)$ pregnant women.

Correlation between Bacteria

Vaginosis and Adverse Pregnancy

Outcome
Table 2 shows the general demographic and reproductive history of the pregnant women. Sixty-six Kuwaitis and 57 non-Kuwaitis were evaluated. BV was diagnosed in $18(32 \%)$ out of the 57 non-Kuwaitis and in only $16(24 \%)$ of the 66 Kuwaitis. An overall prevalence rate of $\mathrm{BV}$ among the pregnant women was $28 \%$. None of the control nonpregnant women had BV. There was also no significant difference in the reproductive history of those with BV and those without ( $\mathrm{p}>$ $0.05)$.

Prevalence of $\mathrm{G}$. vaginalis and Other $B V$-Associated Pathogens in Pregnant

Women with and without $B V$

The association of $G$. vaginalis and other $\mathrm{BV}$-associated pathogens with pregnant women diagnosed as having $\mathrm{BV}$ and non-BV is shown in table 3. G. vaginalis was present in all $(100 \%)$ of the 34 pregnant women with BV but in only $7(8 \%)$ of those without BV $(\mathrm{p}<$ 0.0001). Lactobacillus spp. were reported in a significantly higher number of patients without BV than with BV $(p<0.0001)$. Although $\mathrm{H}_{2} \mathrm{O}_{2}$-producing lactobacilli and Mobiluncus 
Table 3. The prevalence of BV-associated pathogens in pregnant women with and without clinical diagnosis of $\mathrm{BV}$

\begin{tabular}{lcccc}
\hline Vaginal pathogens & \multicolumn{2}{l}{ Women colonized/infected } & Total & p value \\
\cline { 2 - 3 } & $\begin{array}{l}\text { BV group } \\
(\mathrm{n}=34)\end{array}$ & $\begin{array}{c}\text { non-BV group } \\
(\mathrm{n}=89)\end{array}$ & & \\
& & & $(\mathrm{n}=123)$ & \\
\hline Gardnerella vaginalis & $34(100)$ & $7(8)$ & $41(33)$ & $<0.0001$ \\
Lactobacilli & $21(62)$ & $88(99)$ & $109(89)$ & $<0.0001$ \\
$\mathrm{H}_{2} \mathrm{O}_{2}$ lactobacilli & $2(6)$ & $9(10)$ & $11(9)$ & $\mathrm{NS},>0.05$ \\
Mobiluncus & $15(44)$ & $60(67)$ & $75(61)$ & $\mathrm{NS},>0.05$ \\
Mycoplasma hominis & $4(12)$ & $1(1)$ & $5(4)$ & $<0.05$ \\
Ureaplasma urealyticum & $25(74)$ & $12(14)$ & $37(30)$ & $<0.0001$ \\
Candida spp. & $14(41)$ & $20(23)$ & $34(28)$ & $<0.05$ \\
Peptostreptococcus spp. & $26(77)$ & $35(39)$ & $61(50)$ & $<0.001$ \\
Staphylococci & $6(18)$ & $38(43)$ & $44(36)$ & $<0.001$ \\
\hline
\end{tabular}

Number (and percent) of women are given. Staphylococci were mainly coagulase-negative staphylococci.

Table 4. Pregnancy outcome among patients with or without BV

\begin{tabular}{llll}
\hline Outcome & $\begin{array}{l}\text { BV present } \\
(\mathrm{n}=34)\end{array}$ & $\begin{array}{l}\text { No BV } \\
(\mathrm{n}=89)\end{array}$ & p value \\
\hline Preterm labour, $<37$ weeks & $9(27)$ & $7(8)$ & $<0.05$ \\
Preterm PROM, <37 weeks & $7(21)$ & $6(7)$ & $<0.05$ \\
Low birth weight, $<2,500 \mathrm{~g}$ & $5(15)$ & $4(5)$ & $<0.05^{\mathrm{a}}$ \\
IUGR & $3(9)$ & $1(1)$ & $<0.05^{\mathrm{a}}$ \\
Neonatal infections & $2(6)$ & $0(0)$ & \\
Low Apgar score $(<7)$ & $2(6)$ & $0(0)$ & \\
Perinatal mortality & $0(0)$ & $0(0)$ & \\
\hline
\end{tabular}

Number (and percent) of women are given.

a $\chi^{2}$ for both were 3.8 and 4.6 , respectively, which are significant $(\mathrm{p}<$ 0.05 ) without Yates' correction. spp. were found in a higher number of patients without $\mathrm{BV}$ than with $\mathrm{BV}$, the differences were not significant ( $\mathrm{p}>0.05)$. M. hominis was present in $4(12 \%)$ of the 34 women with BV and in only (1\%) of the 89 women without BV. U. urealyticum, Candida spp. and Peptostreptococcus were found in a signif- icantly higher number of patients with $\mathrm{BV}$ than without $B V(p<0.0001, p<0.05$ and $p<$ 0.001 , respectively). On the other hand, staphylococci were reported in significantly more patients without $\mathrm{BV}$ than with $\mathrm{BV}(\mathrm{p}<$ $0.001)$. 


\section{Association of BV with Pregnancy}

\section{Outcome}

The pregnancy outcome differed significantly for patients with and without BV (table 4). Preterm labour prior to 37 weeks gestation occurred among 9 patients $(27 \%)$ out of 34 with BV and 7 (8\%) patients without BV $(\mathrm{p}<0.05)$. Preterm premature rupture of membranes (PROM) also occurred more commonly in patients with $(21 \%)$ than without $(7 \%)$ BV $(p<0.05)$. None of the patients who had preterm labour, PROM or premature delivery had a past obstetric history of previous preterm delivery. Patients with BV had more newborn babies with low birth weight of less than $2,500 \mathrm{~g}$ than those without BV $(15$ versus $5 \% ; p<0.05)$. Nine percent of patients with $\mathrm{BV}$ when compared to $1 \%$ of those without BV had pregnancies with IUGR $(p<0.05)$. Neonatal infections and neonates with low Apgar scores $(<7)$ were observed in 2 patients with $\mathrm{BV}$ and not in those without. Perinatal mortality was not recorded in either of the groups. Cervical infection with Mycoplasma spp. was not independently associated with adverse pregnancy outcome or postpartum fever.

\section{Discussion}

In this study, the overall prevalance of BV among the pregnant population was $28 \%$. Of these, $47 \%$ were Kuwaitis and 53\% nonKuwaitis. The prevalence of BV among the Kuwaiti women was actually $24 \%$ while among the non-Kuwaitis it was $32 \%$. Even though this difference in prevalence rate was not statistically significant it is noteworthy that more Kuwaitis $(n=66)$ than non-Kuwaitis $(n=57)$ were evaluated. The prevalence of $28 \% \mathrm{BV}$ cases in pregnancy in this study is relatively high. The reported prevalence of this disorder in the literature averages about
$10-30 \%$ in pregnant women $[20,21]$. However, a prevalence rate almost as high as ours $(26 \%)$, and a rate nearly twice our findings (52\%), had been reported by Thomason et al. [22] and Govender et al. [23], respectively.

Prematurity is a major problem in obstetric practice, where it is responsible for 70 $80 \%$ of all perinatal deaths, excluding congenital anomalies [20]. Preterm onset of labour and PROM are the main causes of such conditions. A past history of preterm labour is one of the most important risk factors in the reoccurrence of preterm labour and delivery in a subsequent pregnancy. In a much earlier report, Minkoff et al. [24] found no association of BV with adverse pregnancy outcome. However, several other studies have found strong association of this disorder with adverse pregnancy outcome $[5,8,11,19,25-$ 27]. Our findings are in concordance with these previous reports. A relatively high proportion of women with BV had preterm labour (27\%) and PROM (21\%). These observations are statistically significant and much higher than the rates in most of these previous reports. It is worthy of emphasis to note that a past obstetric history of previous preterm delivery was not recorded in any of our patients with preterm labour and PROM, thus underscoring the role of $\mathrm{BV}$ in these adverse outcomes of pregnancy. The absence of postpartum complications in the presence of PROM, in this study, is an important clinical finding and worthy of note. It is possible, and highly likely, that the prophylactic use of antibiotics routinely prescribed for women with PROM prevented the establishment of intra-uterine and postpartum infections. Our study also found that BV was associated with low birth weight and IUGR in a significant proportion of our pregnant women. Although the figure for the IUGR is small, this finding is nonetheless interesting and worthy of further research as the role of $\mathrm{BV}$ in this complication is not 
well understood nor is it well documented in other reports.

The mechanisms involved in the development of BV and preterm onset of labour and PROM are also not very clear. However, it can be speculated that since bacterial lipase and protease produced by the vaginosis-associated pathogens could reduce chorioamniotic membrane strength [20], it is conceivable that this weakness in the membrane could lead to its rupture. High level of phospholipase $\mathrm{A}_{2}$ production has been detected in $G$. vaginalis, Peptostreptococcus, and other anaerobes associated with BV [28]. This compound is known to initiate prostaglandin production by releasing arachidonic acid from its esterified forms and prostaglandin is a potent initiator of onset of labour. This mechanism may explain the role of $\mathrm{BV}$ in the observed increased incidence of preterm labour. An extension of this study in an animal model is required to confirm this line of thinking.

In conclusion, the data generated from this study indicates that, (i) BV is common in our pregnant female population in Kuwait with high prevalence rate of $28 \%$, and (ii) $\mathrm{BV}$ is sig- nificantly associated with preterm labour, PROM, low birth weight and IUGR. The association of $\mathrm{BV}$ with adverse pregnancy outcome is a potentially preventable cause of prematurity. Therefore, should BV be actively sought and treated during pregnancy to prevent an adverse pregnancy outcome? This approach may not be cost-effective. However, since this disorder and other vaginosis-associated infections are an important cause of neonatal morbidity, and since safe and effective therapy during pregnancy is available, treatment of syndromic maternal genital infections, like BV and others, is warranted. An extension of this study is essential to evaluate the influence of treatment of BV on these disorders in pregnancy.

\section{Acknowledgements}

We would like to gratefully acknowledge the financial support of Kuwait University via grant No. MDI 297. Technical support received from Ms. Tina Verghese and Ms. Susan George is well appreciated. The cooperation and assistance of our colleagues at the Maternity Hospital are also given special commendation.

\section{References}

1 Whitfield CR: Vital statistics and derived information for obstetricians; in Whitfield CR (ed): Dewhurst's Textbook for Obstetrics and Gynaecology for Postgraduates, ed 5. Oxford, Blackwell Science Limited, 1995, pp 504-509.

2 McCormick MC: The contribution of low birth weight to infant mortality and childhood morbidity. N Engl J Med 1985;312:82-90.

3 Martius J, Krohn MA, Hillier SL, Stamn WE, Holmes KK, Eschenbach DA: Relationships of vaginal Lactobacillus species, cervical Chlamydia trachomatis and bacterial vaginosis to preterm birth. Obstet Gynecol 1988;71:89-95.
4 Gravett MG, Nelson HP, DeRouen $\mathrm{T}$, Chritchlow C, Eschenbach DA, Holmes KK: Independent association of bacterial vaginosis and Chlamydia trachomatis with adverse pregnancy outcome. JAMA 1986; 256:1899-1903.

5 Kurki T, Sivonen A, Renkonen OV, Savia E, Ylikorkala O: Bacterial vaginosis in early pregnancy and pregnancy outcome. Obstet Gynecol 1992;80:173-177.

6 Martins J, Eschenbach DA: The role of bacterial vaginosis as a cause of amniotic fluid infection, chorioamnionitis and prematurity: A review. Arch Gynecol Obstet 1990;247:113.
7 Gravett MG, Hummel D, Eschenbach DA, Holmes KK: Preterm labour associated with subclinical amniotic infection and with preterm labour. Obstet Gynecol 1986;67:229_ 237.

8 Platz-Christensen JJ, Pernevi P, Andersson Brandberg A, Wiqvist N: A longitudinal follow-up of bacterial vaginosis during pregnancy. Acta Obstet Gynecol Scand 1993;72:99_ 102.

9 Rai R, Clifford K, Regan L: The modern preventative treatment of recurrent miscarriage: A review. $\mathrm{Br}$ J Obstet Gynaecol 1996;103:106110. 
10 Hay PE, Lamont RF, Taylor-Robinson D, Morgan DJ, Ison C, Pearson $\mathrm{J}$ : Abnormal bacterial colonisation of the genital tract and subsequent preterm delivery and late miscarriage. BMJ 1994;308:295-298.

11 Meis PJ, Goldenberg RL, Merver B, Moawad A, Das A, McNellis D, Johnson F, Iams JD, Thom E, Andrews WW: The preterm prediction study: Significance of vaginal infections. Am J Obstet Gynecol 1995; 173:1231-1235.

12 Hay PE, Morgan TJ, Ison CA, Bhide SA, Romney M, McKenzie P, Pearson J, Lamont RF, Taylor-Robinson D: Longitudinal study of bacterial vaginosis during pregnancy. $\mathrm{Br} \mathrm{J}$ Obstet Gynecol 1994;101:10481053.

13 McDonald HM, O'Loughlin J, Vigneswaran R, Jolley PT, McDonald PJ: Bacterial vaginosis in pregnancy and efficacy of short course oral metronidazole treatment: A randomised controlled trial. Obstet Gynecol 1994;84:343-348.

14 Holst E, Wathne B, Hovelius B, Mardh PA: Bacterial vaginosis: Microbiological and clinical findings. Eur J Clin Microbiol 1987;6:536541.

15 Rosenstein IJ, Morgan DJ, Sheehan M, Lamont RF, Taylor-Robinson D: Bacterial vaginosis in pregnancy: Distribution of bacterial species in different gram-stain categories on the vaginal flora. J Med Microbiol 1996;45:120-126.
16 Rotimi VO, Yakubu Z, Abudu OO, Banjo TO: Direct Gram's stain of vaginal discharge as a means of diagnosing bacterial vaginosis. $\mathrm{J}$ Med Microbiol 1991;35:103-106.

17 Oji GO, Rotimi VO: Gardnerella vaginalis in non-specific vaginitis: Isolation and identification. Af $\mathbf{J}$ Clin Microbiol 1984;1:39-46.

18 McGroarty JA, Tomeczek L, Pond DG, Reid G, Bruce AW: Hydrogen peroxide production by Lactobacillus species: Correlation with susceptibility to the spermicidal compound Nonoxynol-9. J Infect Dis 1992;165:1142-1144.

19 Baron EJO, Peterson IR, Finegold SM: Bailey and Scott's Diagnostic Microbiology, 9th edn. Baltimore, Mosby, 1994, pp 355-359, 696697.

20 Biswas MK: Bacterial vaginosis. Clin Obstet Gynecol 1993;36:166176.

21 Mead PB: Epidemiology of bacterial vaginosis. Am J Obstet Gynecol 1993; 169:446-449.

22 Thomason JL, Gelbart SM, Wilcoski LM, Peterson AK, Jilly BJ, Hamilton PR: Proline aminopeptidase activity as a rapid diagnostic test to confirm bacterial vaginosis. Am J Obstet Gynecol 1988;71:607-611.
23 Governder L, Hoosen AA, Moodley J, Moodley P, Sturm AW: Bacterial vaginosis and associated infections in pregnancy. Int $\mathbf{J}$ Gynecol Obstet 1996;55:23-28.

24 Minkoff H, Grunebaum A, Schwarz $\mathrm{RH}$, Feldman J, Cummings $\mathrm{M}$, Crombleholme W, Clark L, Pringle G, McCormarck WM: Risk factors for prematurity and premature rupture of membranes: A prospective study of the vaginal flora in pregnancy. Am J Obstet Gynecol 1984;150: 965-972.

25 Gratacos E, Figueras F, Barranco M, Vila J, Gararach V, Alonso PL, Fortuny A: Spontaneous recovery of bacterial vaginosis during pregnancy is not associated with an improved perinatal outcome. Acta Obstet Gynecol Scand 1998;77:37-40.

26 Lamont RF, Taylor-Robinson D, Newman M, Wigglesworth J, Elder MG: Spontaneous early preterm labour associated with abnormal genital bacterial colonization. $\mathrm{Br} \mathrm{J}$ Obstet Gynaecol 1986;93:804-810.

27 McGregor JA, French JI, Seo K: Premature rupture of membranes and bacterial vaginosis. Am J Obstet Gynecol 1993;169:463-466.

28 Gravett MG, Nelson HP, DeRouen T, Critchlow C, Eschenbach DD, Holmes KK: Independent associations of bacterial vaginosis and Chlamydia trachomatis infection with adverse pregnancy outcome. JAMA 1986;256:1899-1903. 